\title{
Quantitative volumetric metabolic measurement of solitary pulmonary nodules by F-18 fluorodeoxyglucose positron emission tomography-computed tomography
}

\author{
Soliter pulmoner nodüllerin F-18 florodeoksiglikoz pozitron emisyon tomografisi-bilgisayarlı tomografi ile \\ kantitatif volümetrik metabolik ölçümü
}

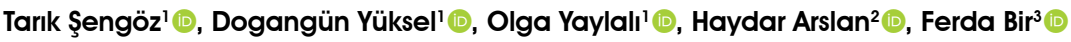 \\ Institution where the research was done: \\ Pamukkale University Medical Faculty, Denizli, Turkey \\ Author Affiliations: \\ 'Department of Nuclear Medicine, Pamukkale University Medical Faculty, Denizli, Turkey \\ ${ }^{2}$ Department of Nuclear Medicine, Trabzon Training and Research Hospital, Trabzon, Turkey \\ ${ }^{3}$ Department of Pathologhy, Pamukkale University Medical Faculty, Denizli, Turkey
}

\section{ABSTRACT}

Background: This study aims to evaluate the effect of quantitative volumetric metabolic measurements in F-18 fluorodeoxyglucose positron emission tomographycomputed tomography to distinguish benign and malignant solitary pulmonary nodules.

Methods: We retrospectively reviewed 78 patients (56 males; 22 females; mean age $61 \pm 11.9$ years; range, 32 to 82 years) with solitary pulmonary nodules who underwent F-18 fluorodeoxyglucose positron emission tomography-computed tomography. Patients were classified as benign, malignant and metastatic lesions according to pathology results. Metabolic volume, maximum standardized uptake value, mean standardized uptake value, maximum metabolic index and mean metabolic index were measured. Mean, median and standard error values were calculated for each group. Nonparametric tests were used for the comparison of each group. Partial correlation analysis was used for the relationship between parameters. For all parameters, cut-off values were obtained with receiver operating characteristic analysis.

Results: Of 78 lesions, 10 were benign (12.8\%), 38 were primary lung carcinoma $(48.7 \%)$ and 30 were metastatic lung nodules $(38.5 \%)$. There was a significant difference between benign lesions and primary lung cancer and between primary lung cancer and metastatic groups in all parameters $(\mathrm{p}<0.05)$. We determined highly significant positive correlation between maximum standardized uptake value and maximum metabolic index $(\mathrm{r}=0.73 ; \mathrm{p}<0.05)$, and moderate positive correlation between mean standardized uptake value and mean metabolic index $(r=0.56$; $\mathrm{p}<0.05$ ). In receiver operating characteristic analysis, maximum standardized uptake value and mean standardized uptake value were found to be the most sensitive and specific methods for benign/malignant discrimination. In the cut-off value $=2.59$, the sensitivity and specificity for maximum standardized uptake value were $98.0 \%$ and $91.7 \%$, respectively. In the cut-off value $=1.65$, the sensitivity and specificity for mean standardized uptake value were $94.0 \%$ and $91.7 \%$, respectively. Conclusion: Maximum metabolic index value is highly correlated with maximum standardized uptake value in benign/malignant solitary pulmonary nodules discrimination by F-18 fluorodeoxyglucose positron emission tomographycomputed tomography. Maximum metabolic index can also be used for discrimination of primary/metastatic malignant lesions.

Keywords: F-18 fluorodeoxyglucose positron emission tomography-computed tomography, metabolic index, solitary pulmonary nodule, standardized uptake value.
$\ddot{O} Z$

Amaç: Bu çalışmada benign ve malign soliter pulmoner nodülleri ayırmak için F-18 florodeoksiglikoz pozitron emisyon tomografisi-bilgisayarlı tomografide kantitatif volümetrik metabolik ölçümlerin etkisi değerlendirildi.

Çalışma planı: F-18 florodeoksiglikoz pozitron emisyon tomografisi-bilgisayarlı tomografi uygulanan, soliter pulmoner nodülleri olan 78 hasta (56 erkek; 22 kadın; ort. yaş $61 \pm 11.9$ yıl; dağılım, 32-82 yıl) retrospektif olarak değerlendirildi. Hastalar patoloji sonuçlarına göre benign, malign ve metastatik lezyonlar olarak sınıflandırıldı. Metabolik volüm, maksimum standardize tutulum değeri, ortalama standardize tutulum değeri, maksimum metabolik indeks ve ortalama metabolik indeks ölçüldü. Her grup için ortalama, ortanca ve standart hata değerleri hesaplandı. Her grubun karşılaştırılması için nonparametrik testler kullanıldı. Parametrelerin arasındaki ilişki için parsiyel korelasyon analizi kullanıldı. Tüm parametreler için sınır değerler alıcı işletim karakteristik analizi ile elde edildi.

Bulgular: Yetmiş sekiz lezyonun 10'u benign (\%12.8), 38'i primer akciğer karsinomu (\%48.7) ve 30'u metastatik akciğer nodülü (\%38.5) idi. Tüm parametrelerde benign lezyonlar ile primer akciğer kanseri arasında ve primer akciğer kanseri ve metastatik gruplar arasında anlamlı farklılık vardı $(\mathrm{p}<0.05)$. Maksimum standardize tutulum değeri ve maksimum metabolik indeks arasında anlamlı pozitif ilişki $(\mathrm{r}=0.73 ; \mathrm{p}<0.05)$, ortalama standardize tutulum değeri ve ortalama metabolik indeks arasında orta pozitif ilişki $(r=0.56 ; \mathrm{p}<0.05)$ saptandi. Alıcı işletim karakteristik analizinde, maksimum standardize tutulum değeri ve ortalama standardize tutulum değerinin benign/malign ayrımında en hassas ve özgül yöntemler olduğu bulundu. Sınır değer=2.59 iken maksimum standardize tutulum değeri için duyarlılık ve özgüllük sırasıyla \%98.0 ve \%91.7 idi. Sınır değer=1.65 iken ortalama standardize tutulum değeri için duyarlılık ve özgüllük sırasiyla $\% 94.0$ ve $\% 91.7$ idi.

Sonuç: Maksimum metabolik indeks değeri F-18 florodeoksiglikoz pozitron emisyon tomografisi-bilgisayarlı tomografi ile benign/malign soliter pulmoner nodüllerin ayrımında maksimum standardize tutulum değeri ile yüksek derecede ilişkilidir. Maksimum metabolik indeks primer/metastatik malign lezyonların ayrımında da kullanılabilir.

Anahtar sözcükler: F-18 florodeoksiglikoz pozitron emisyon tomografisi-bilgisayarlı tomografi, metabolik indeks, soliter pulmoner nodül, standardize tutulum değeri.

Received: November 20, 2018 Accepted: June 13, 2019 Published online: October 23, 2019

Correspondence: Tarık Şengöz, MD. Pamukkale Üniversitesi Tıp Fakültesi Nükleer Tıp Anabilim Dalı, 20070 Kınıklı, Denizli, Turkey. Tel: +90258 - 2965306 e-mail: tsengoz@pau.edu.tr 
Circular pulmonary nodules smaller than $3 \mathrm{~cm}$, surrounded by normal lung tissue and not accompanied by lymph nodes, atelectasis, or pneumonia, are defined as solitary pulmonary nodules (SPNs) ${ }^{[1]}$ Although most SPNs are benign, around 30-40\% are malignant. ${ }^{[2]}$ Early diagnosis and exclusion of malignancy are important for successful treatment of SPNs. Correct diagnosis of malignant nodules is essential for preventing false diagnosis of lung cancer and unnecessary, costly and invasive diagnostic procedures. Solitary pulmonary nodule can be diagnosed noninvasively by computed tomography (CT), magnetic resonance imaging (MRI) and F-18 fluorodeoxyglucose (FDG) positron emission tomography (PET)-CT. Fluorodeoxyglucose PET-CT can distinguish benign from malignant nodules. ${ }^{[3]}$ Fluorodeoxyglucose is a glucose analog used in PETCT. Fluorodeoxyglucose is taken up at a high rate by malignant cells because of their increased glucose metabolism. ${ }^{[4]}$ In a retrospective study, the sensitivity and specificity of F-18 FDG PET-CT were 97\% and $85 \%$, respectively, in patients with SPN with FDG uptake. ${ }^{[5]}$ In contrast, the probability of malignancy in nodules without FDG involvement is very low. ${ }^{[6,7]}$ However, FDG uptake by activated macrophages in the presence of infection and/or inflammation can lead to false-positive results. In addition, false negativity may be seen in some types of tumor; e.g., carcinoid, bronchoalveolar, and mucinous cancers. ${ }^{[8,9]}$

The commonly used standardized uptake value (SUV) is a semi-quantitative analysis parameter for PET images. ${ }^{[8]}$ The maximum SUV $\left(\mathrm{SUV}_{\max }\right)$ is obtained for a one-pixel region of interest corresponding to the maximum pixel value in the tumor. However, $\mathrm{SUV}_{\max }$ does not reflect the total tumor glycolytic activity for the whole tumor mass in FDG PET. Although $S U V_{\text {mean }}$ may be more suitable than $\mathrm{SUV}_{\max }$ for describing total tumor glycolytic activity, the heterogeneous tumor uptake may reduce $\mathrm{SUV}_{\text {mean }}$ excessively. ${ }^{[10]}$ Another way of evaluation of total tumor glycolytic activity is to use volumetric PET parameters such as metabolic tumor volume (MTV) and total lesion glycolysis. Metabolic tumor volume is a volumetric measurement of tumor cells with high glycolytic activity. Volumetric parameters are usually researched for prognostic purposes or the prediction of therapeutic response. ${ }^{[10]}$ However, there is limited study about the diagnostic usage of volumetric PET parameters for discrimination of malign lesions from benign lesions. As a volumetric PET parameter, the metabolic index (MI) is calculated by multiplying the MTV by the SUV (maximum or mean) and is used to evaluate the prognosis of some types of tumor. ${ }^{[11]}$ In this study, we aimed to evaluate the effect of quantitative volumetric metabolic measurements in F-18 FDG PET-CT to distinguish benign and malignant SPNs.

\section{PATIENTS AND METHODS}

This study was conducted at Pamukkale University Medical Faculty. In total, 111 patients with SPN who applied between November 2015 and December 2017 and underwent F-18 FDG PET-CT imaging were evaluated retrospectively. All patients were sent from the department of chest diseases. The diagnosis and follow-up parameters of patients with SPN were performed in accordance with the European Society of Radiology and the European Respiratory Society guideline (Eur Respir J 2015; 46: 61-79). Thirty-three patients were excluded from the study; 16 were not pathologically evaluated and 17 did not match a diagnosis of SPN; therefore, a total of 78 patients (56 males; 22 females; mean age $61 \pm 11.9$ years; range, 32 to 82 years) were evaluated. All patients underwent a preoperative bronchoscopic procedure. All lesions were verified histopathologically. The following procedures were used for histopathological diagnosis: 36 (46.2\%) transthoracic needle biopsies, 35 (44.8\%) wedge resections, two (2.6\%) lobectomies, two (2.6\%) pneumonectomies, three $(3.8 \%)$ thoracenteses. Patients who underwent surgical procedure underwent the following methods: 20 thoracotomies and 15 video-assisted thoracic surgeries. The study protocol was approved by the Pamukkale University Medical Faculty Ethics Committee. A written informed consent was obtained from each patient. The study was conducted in accordance with the principles of the Declaration of Helsinki.

The patients were divided into benign and malignant groups based on the pathology results. Patients in the malignant group were classified into primary lung cancer and metastatic nodule subgroups. Immunohistochemical analysis was performed to all patients in the malignant and metastatic groups during pathological evaluation.

After fasting and resting for six $\mathrm{h}$, the patients received 259-407 $\mathrm{MBq}$ (7-11 $\mathrm{mCi}$ ) of F-18 FDG intravenously when their fasting blood glucose level was $<200 \mathrm{mg} / \mathrm{dL}$. All patients were screened $60 \mathrm{~min}$ after injection. Pre-injection activity and postinjection injector activity were counted in PET-CT. The actual dose of radioactivity given to the patient was thus calculated. The patients were examined using a dedicated PET/CT scanner (Gemini TF TOF PET-CT; Philips Healthcare, Cleveland, OH, USA; $3 \mathrm{D}$ mode, slice thickness of $5 \mathrm{~mm}, 4 \times 4 \times 22 \mathrm{~mm}$ LYSO 
crystal, number of crystals $28.336,256 \times 256$ matrix (voxel size $2.6 \times 2.6 \times 2.4 \mathrm{~mm}^{3}$ ), transverse field of view (FOV) $576 \mathrm{~mm}$ and axial FOV $180 \mathrm{~mm}$ ). Emission scans were acquired from the calvaria base to the middle of the thigh for $1.5 \mathrm{~min}$ per position without intravenous contrast medium injection. Transmission images were obtained by low-dose CT (50-120 mAs, 90-140 kVp, 16 number of CT detectors, slice thickness of $5 \mathrm{~mm}$ ). Attenuation correction was performed for PET images using CT findings and the ordered subsetsexpectation maximization algorithm (33 subsets, three iterations). Positron emission tomography images were reconstructed by the iterative method. Transverse, sagittal, and coronal sections (5 $\mathrm{mm}$ thickness) were created from PET-CT fusion images and evaluated using Philips Fusion Viewer software (version 2.1; Philips Healthcare, Best, The Netherlands).

The images were transferred to Tumor Tracking EBW NM 2.0 (Philips Healthcare, Cleveland, OH, USA) to calculate metabolic parameters. This software has three methods for calculating metabolic parameters: the bounded (limited), threshold, and interactive methods. Using the bounded method, volumetric areas of interest (VOIs) were automatically drawn around all lung nodules in PET/CT fusion axial images using a VOI limit of $42.5 \%$ (40-60\%) without considering background activity (mediastinal blood pool, liver, contralateral lung, etc.). And then, the isocontours were manually adjusted so that the lesion border on PET and CT overlapped. Sagittal and coronal PET-CT fusion sections were reviewed to confirm that the lesion was included in the VOI in all three sections. Lesion size and volume were measured in millimeters and milliliters. The metabolic volume, $\mathrm{SUV}_{\max }$, and $\mathrm{SUV}_{\text {mean }}$ of VOIs were automatically calculated and the maximum metabolic index $\left(\mathrm{MI}_{\max }\right.$; $\mathrm{SUV}_{\max } \times$ metabolic volume) and mean metabolic index $\left(\mathrm{MI}_{\text {mean }} ; \mathrm{SUV}_{\text {mean }} \times\right.$ metabolic volume $)$ values were determined.

\section{Statistical analysis}

The PASW for Windows version 17.0 software (SPSS Inc., Chicago, IL, USA) was used for statistical analysis. Mean and median values were calculated. Nonparametric tests were used to compare mean values. The correlations of measurement methods were assessed by partial correlation analysis. Receiver operating characteristic (ROC) analysis was performed to assess the ability of the parameters to differentiate benign from malignant lesions and threshold values were calculated. $\mathrm{P}$ values $<0.05$ were deemed to indicate statistical significance.

\section{RESULTS}

The histopathological diagnosis was benign in 10 $(12.8 \%)$ and malignant in 38 (48.7\%) lesions; 30 (38.5\%) of the 78 lesions were metastatic lung nodules. Nodule sizes in benign, primary lung cancer and metastatic groups were $15.9 \pm 5.4 ; 26.6 \pm 7.6 ; 15.8 \pm 5.6 \mathrm{~mm}$,

Table 1. Histopathologic results of benign, malignant and metastatic solitary pulmonary nodules

\begin{tabular}{|c|c|c|c|c|c|}
\hline Benign SPNs $(n=10)$ & $\mathrm{n}$ & Malignant SPNs $(n=38)$ & $\mathrm{n}$ & Metastatic SPNs $(n=30)$ & $\mathrm{n}$ \\
\hline Pneumonitis & 3 & Squamous cell carcinoma & 16 & Lymphoma & 5 \\
\hline Chronic inflammation & 2 & Adenocarcinoma & 13 & Pancreas cancer & 3 \\
\hline Hamartoma & 2 & Small cell carcinoma & 9 & Breast cancer & 3 \\
\hline Granuloma & 1 & & & Malignant melanoma & 2 \\
\hline Neuroendocrine cell hyperplasia & 1 & & & Colon cancer & 2 \\
\hline \multirow[t]{10}{*}{ Pneumoconiosis } & 1 & & & Laryngeal cancer & 2 \\
\hline & & & & Stomach cancer & 2 \\
\hline & & & & Rectum cancer & 2 \\
\hline & & & & Bladder cancer & 2 \\
\hline & & & & Cervical cancer & 2 \\
\hline & & & & Neuroendocrine tumor & 1 \\
\hline & & & & Adrenal cancer & 1 \\
\hline & & & & Multiple myeloma & 1 \\
\hline & & & & Esophageal cancer & 1 \\
\hline & & & & Osteosarcoma & 1 \\
\hline
\end{tabular}

SPN: Solitary pulmonary nodule. 


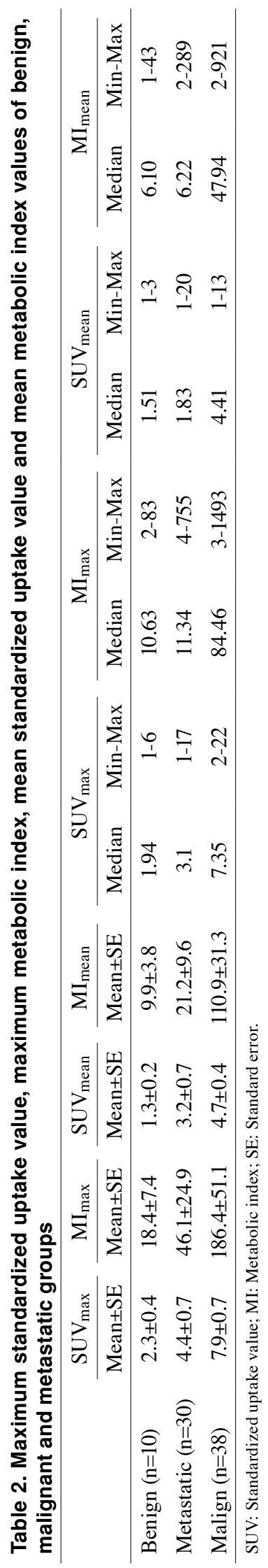

respectively. All lesions were histopathologically diagnosed (Table 1).

There were nine small-cell lung cancers (SCLCs) (17\%) and 29 non-SCLCs (83\%) in 38 patients with primary lung cancer (Table 1). The lesions diagnosed as malignant by PET-CT were pathologically defined as primary lung cancer (true positive), and the 10 lesions diagnosed as benign by PET-CT were pathologically defined as benign. The remaining two lesions were defined as histopathologically (false-negative) as lung cancer (adenocancer, mixed type).

The mean and median $\mathrm{SUV}_{\max }, \mathrm{SUV}_{\text {mean }}, \mathrm{MI}_{\max }$, and $\mathrm{MI}_{\text {mean }}$ were lowest in the benign group and highest in the primary lung cancer group. A nonparametric Kruskal-Wallis test showed significant differences among the three groups $(\mathrm{p}=0.001 ; \mathrm{p}=0.027 ; \mathrm{p}=0.004$; $\mathrm{p}=0.017$, respectively). Significant differences were found in $\mathrm{SUV}_{\max }, \mathrm{MI}_{\max }, \mathrm{SUV}_{\text {mean }}$ and $\mathrm{MI}_{\text {mean }}$ between the benign-primary lung cancer $(\mathrm{p}=0.001 ; \mathrm{p}=0.010$;

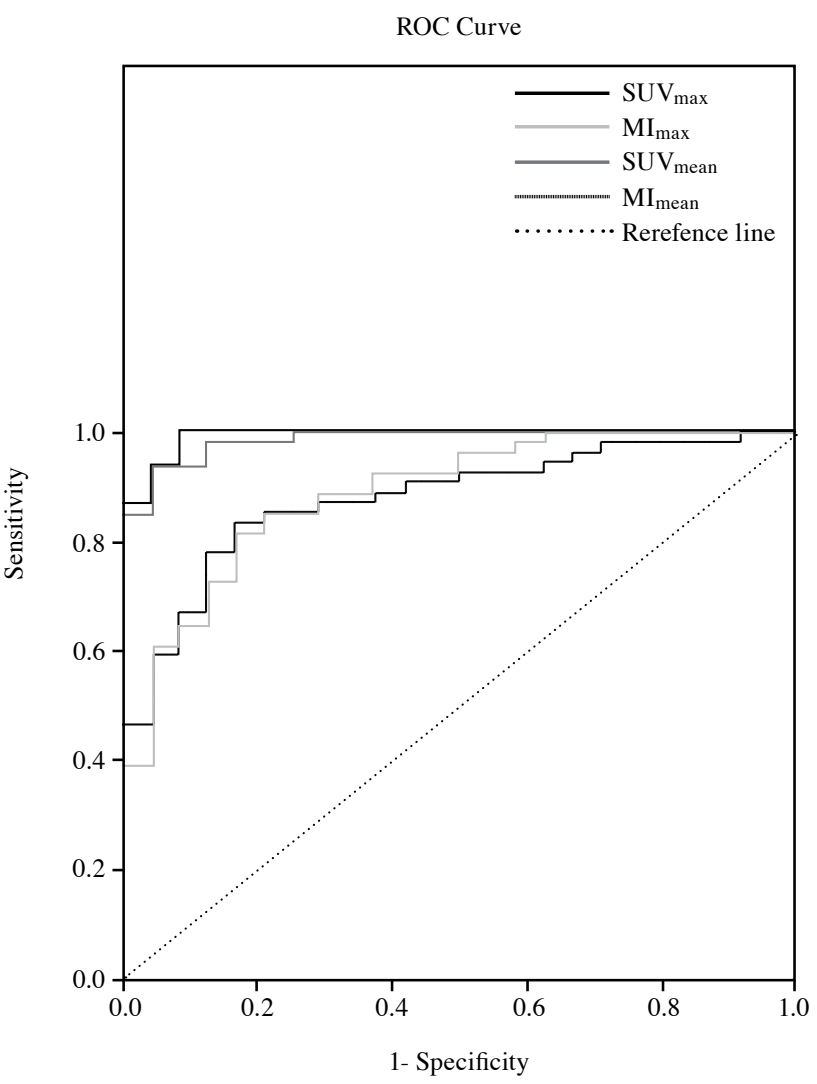

Figure 1. Receiver operating characteristic analysis of maximum standardized uptake value, maximum metabolic index, mean standardized uptake value, and mean metabolic index ratio.

ROC: Receiver operating characteristic; SUV: Standardized uptake value; MI: Metabolic index. 

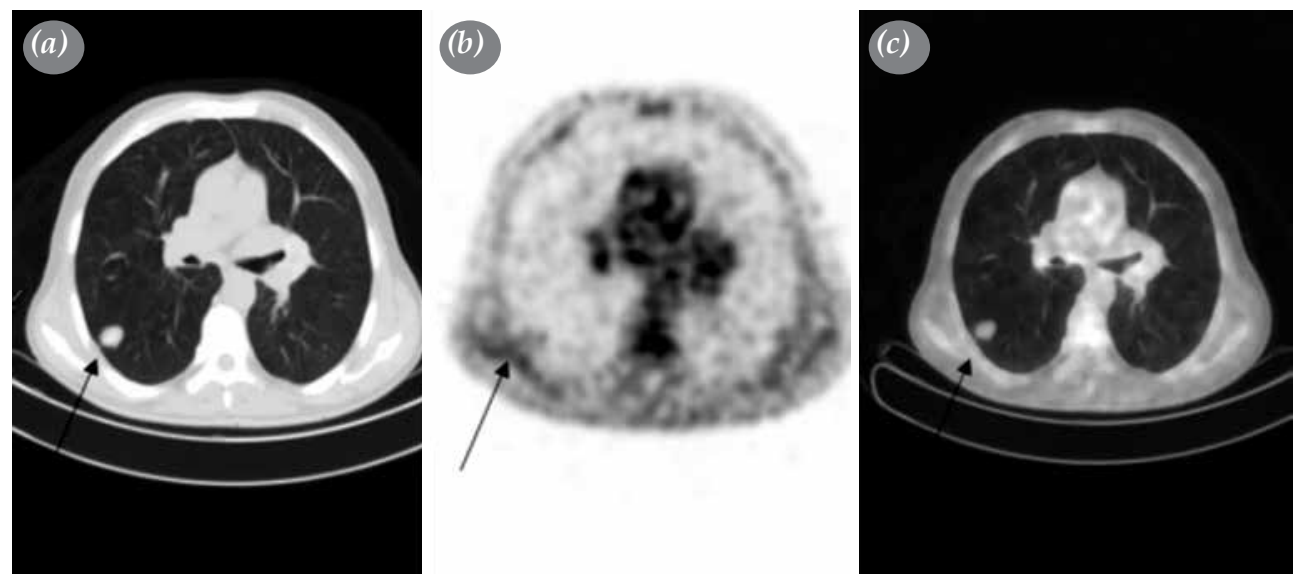

Figure 2. Positron emission tomography/computed tomography of a 60-year-old male patient with a solitary pulmonary nodule (arrows) on right lung (true negative on scan). Maximum standardized uptake value: 1.77 , maximum metabolic index: 15.94 , mean standardized uptake value: 0.94 , mean metabolic index: 8.46. (a) computed tomography, (b) computed tomography-attenuated positron emission tomography, (c) fusion positron emission tomography/computed tomography (histopathology: organized pneumonia).

$\mathrm{p}=0.002 ; \mathrm{p}=0.045$, respectively) and metastatic-primary lung cancer groups $(\mathrm{p}=0.001 ; \mathrm{p}=0.018 ; \mathrm{p}=0.040$; $\mathrm{p}=0.010$, respectively) by Mann-Whitney $U$ test. The $\mathrm{SUV}_{\max }$ and $\mathrm{SUV}_{\text {mean }}$ differed significantly between the benign and metastatic lung lesion groups $(\mathrm{p}=0.010$; $\mathrm{p}=0.088$, respectively) (Table 2 ).

There was a significant correlation $(r=0.73$; $\mathrm{p}=0.001$ ) between $\mathrm{SUV}_{\max }$ and $\mathrm{MI}_{\max }$, and a moderate correlation between $\mathrm{SUV}_{\text {mean }}$ and $\mathrm{MI}_{\text {mean }}(\mathrm{r}=0.56$; $\mathrm{p}=0.001$ ).

The ROC analysis showed that $\mathrm{SUV}_{\max }$ and SUV $V_{\text {mean }}$ were more significant than $\mathrm{MI}_{\max }$ and $\mathrm{MI}_{\text {mean }}$ (Figure 1). The cut-off values that provided the optimal sensitivity and specificity were 2.59 for $\mathrm{SUV}_{\max }$ (sensitivity $98 \%$, specificity $91.7 \%$ ), 1.65 for $\mathrm{SUV}_{\text {mean }}$ (sensitivity $94 \%$, specificity $91.7 \%$ ), 9.27 for $\mathrm{MI}_{\max }$ (sensitivity $92.6 \%$, specificity $72.5 \%$ ), and 5.40 for $\mathrm{MI}_{\text {mean }}$ (sensitivity $89 \%$, specificity $91.7 \%$ ) (Table 3).

\section{DISCUSSION}

Determination of risk for malignancy of SPNs is important. F-18 FDG PET-CT allows noninvasive assessment of the metabolic function of tumoral lesions. ${ }^{[12]}$ The SUV is a semiquantitative parameter that reflects FDG uptake and reportedly facilitates differentiation of benign from malignant pulmonary nodules. ${ }^{[13-16]}$ We found significant differences in $S U V_{\max }$ and $S U V_{\text {mean }}$ among the benign, primary lung cancer, and metastatic lung cancer groups $(\mathrm{p}<0.05)$. The mean $\mathrm{SUV}_{\max }$ and $\mathrm{SUV}_{\text {mean }}$ were $2.3 \pm 0.4$ and $1.3 \pm 0.2$ for the benign group, $7.9 \pm 0.7$ and $4.7 \pm 0.4$ for primary lung cancer group, and $4.4 \pm 0.7$ ) and $3.2 \pm 0.7$ for metastatic lung cancer group, respectively.

Table 3. Sensitivity, specificity and area under the curve values of threshold value for maximum standardized uptake value, maximum metabolic index, mean standardized uptake value, and mean metabolic index

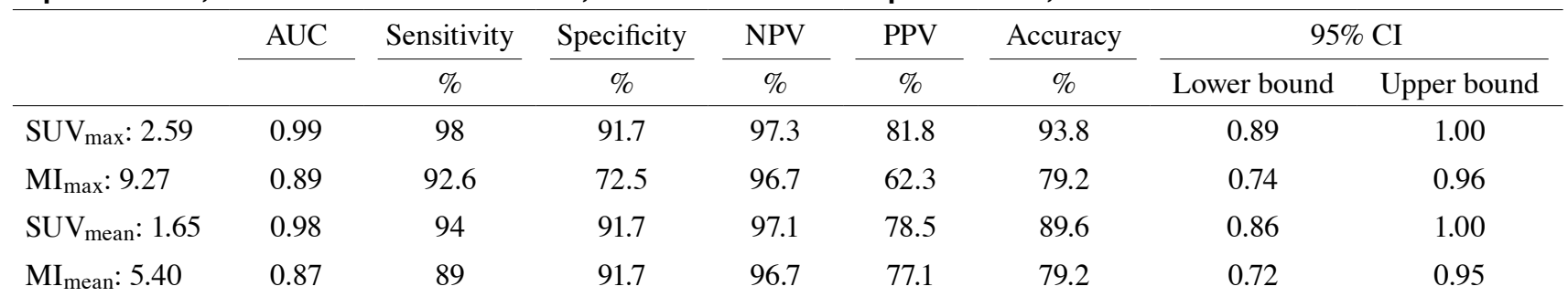

AUC: Area under the curve; NPV: Negative predictive value; PPV: Positive predictive value; CI: Confidence Interval SUV: Standardized uptake value; MI: Metabolic index. 
Zhao et al. ${ }^{[13]}$ reported that among 175 SPNs, the $\mathrm{SUV}_{\max }$ was $1.9 \pm 1.4$ in the benign group and $4.9 \pm 4.1$ in the malignant group; the difference was significant. Lopez et al. ${ }^{[17]}$ reported that among 55 SPN lesions, the $\mathrm{SUV}_{\max }$ was $2.3 \pm 1.3$ and $4.5 \pm 2.8$ in benign and malignant groups, respectively. Similarly, in our study, the $\mathrm{SUV}_{\max }$ and $\mathrm{SUV}_{\text {mean }}$ of malignant lesions were significantly higher than those of benign lesions. Yilmaz and Tasdekin ${ }^{[14]}$ reported $\mathrm{SUV}_{\max }$ values of 241 benign, malignant, and metastatic SPN lesions of $3.5 \pm 3.0,7.7 \pm 4.1$, and $3.2 \pm 3.1$, respectively. The mean $\mathrm{SUV}_{\max }$ of malignant lesions was significantly higher than that of benign lesions, while the mean $\mathrm{SUV}_{\max }$ did not differ significantly between the benign and metastatic lesions. In contrast, in our study, the $\mathrm{SUV}_{\max }$ of metastatic lesions was significantly higher than that of benign lesions.

The SUV provides information on metabolic activity independent of lesion size. The MTV is defined as the volume of tumor tissue showing increased FDG uptake and is regarded as a prognostic factor. ${ }^{[18]}$ The SUV provides only information on metabolic activity, while MTV reflects the proportion of the lesion that shows high metabolic activity. We aimed to identify a parameter that enables effective differentiation of benign from malignant SPNs by combining the SUV and MTV; i.e., the MI. Xie et al. ${ }^{[1]}$ reported that $\mathrm{MI}$ is significantly related to the prognosis of nasopharyngeal carcinoma. To our knowledge, no study has reported that MI is predictive of malignancy in SPNs. In our study, the $\mathrm{MI}_{\max }$ values were $18.4 \pm 7.4,46.1 \pm 24.9$, and $186.4 \pm 51.1$ in the benign, metastatic, and malignant groups, respectively. Significant differences were found in $\mathrm{MI}_{\max }$ between the benign-primary lung cancer and between primary lung cancer-metastatic group.

In the ROC analysis, the cut-off values that provided the optimal sensitivity and specificity were 2.59 for SUV $_{\max }$ (sensitivity 98\%, specificity 91.7\%), 1.65 for $\mathrm{SUV}_{\text {mean }}$ (sensitivity 94\%, specificity 91.7\%), 9.27 for $\mathrm{MI}_{\max }$ (sensitivity $92.6 \%$, specificity $72.5 \%$ ), and 5.40 for $\mathrm{MI}_{\text {mean }}$ (sensitivity $89 \%$, specificity $91.7 \%$ ). The areas under the curve showed that $\mathrm{SUV}_{\max }$ and $\mathrm{SUV}_{\text {mean }}$ were more effective than $\mathrm{MI}_{\text {max }}$ and $\mathrm{MI}_{\text {mean }}$ for differentiation of benign from malignant SPNs. Various optimal cut-off $\mathrm{SUV}_{\max }$ values for prediction of malignancy have been reported. Demir et al. ${ }^{[19]}$ reported that a $S U V_{\text {max }}$ cut-off of $>2.5$ had a sensitivity of $94 \%$ and specificity of $75 \%$. In a study involving 186 patients, a SUV $\max$ cut-off of 2.5 had a sensitivity of $86.7 \%$ and specificity of $50 \% .^{[15]}$ Several studies support a $\mathrm{SUV}_{\max }>2.5$ as the cut-off for differentiation of benign from malignant lesions by PET/CT. ${ }^{[8,20-22]}$ Nguyen et al., ${ }^{[23]}$ in a retrospective study involving 143 patients, showed that a $\mathrm{SUV}_{\max }$ cut-off of $>3.6$ had a sensitivity and specificity of $81 \%$ and $94 \%$, respectively. $\mathrm{Yi}$ et al. ${ }^{[24]}$ conducted a study with 119 patients: a cut-off $\mathrm{SUV}_{\max }$ of $>3.5$ had a sensitivity of $96 \%$ and a specificity of $88 \%$. In the retrospective study by Lopez et al. ${ }^{[17]}$ involving 55 patients, a SUV $\max$ cut-off of $>1.95$ had a sensitivity of $80 \%$ and specificity of $53.3 \%$. As the $\mathrm{SUV}_{\max }$ cut-off increases, the sensitivity decreases, and the specificity increases. In contrast, as the $\mathrm{SUV}_{\max }$ decreases, the specificity decreases significantly. No consensus regarding the $\mathrm{SUV}_{\max }$ cut-off that provides the best diagnostic performance has been established. In this study, a SUV $\mathrm{Sax}_{\max }$ cut-off of $>2.59$ provided good sensitivity and specificity, in agreement with most previous reports. ${ }^{[19-22]}$

To our knowledge, no previous study has evaluated the usefulness of MI for the diagnosis of SPN. In this study, $\mathrm{MI}_{\max }$ and $\mathrm{MI}_{\text {mean }}$ cut-offs of $>9.27$ and $>5.40$ provided the best diagnostic performance. In the ROC analysis, $\mathrm{SUV}_{\max }$ and $\mathrm{SUV}_{\text {mean }}$ were more significant than $\mathrm{MI}_{\text {max }}$ and $\mathrm{MI}_{\text {mean. Some large SPN lesions had }}$ low SUV values and some small SPN lesions had high SUV values, possibly due to differences in metabolic volume.

There was a significant correlation between $\mathrm{SUV}_{\max }$ and $\mathrm{MI}_{\max }(\mathrm{r}=0.73 ; \mathrm{p}=0.001)$, and a moderately significant correlation between $\mathrm{SUV}_{\text {mean }}$ and $\mathrm{MI}_{\text {mean }}$ $(\mathrm{r}=0.56 ; \mathrm{p}=0.001)$. Therefore, $\mathrm{MI}_{\max }$ can be used together with $\mathrm{SUV}_{\max }$ for differentiation of benign from malignant lesions.

In our study, 30 of 78 SPNs were metastatic lung nodules $(38.5 \%)$. Few studies have investigated the SUVs of metastatic lung nodules and benign or malignant primary lung lesions. Yilmaz and Tastekin, ${ }^{[14]}$ reported mean $\mathrm{SUV}_{\max }$ values of $3.5 \pm 3.0,7.7 \pm 4.1$, and $3.2 \pm 3.1$ for benign, malignant, and metastatic lesions, respectively. There was a significant difference between the malignant and metastatic groups, but not between the benign and metastatic groups. In our study, the $\mathrm{SUV}_{\max }$ values differed significantly among the three groups, but the MI values were not significantly different between the benign and metastatic nodule groups. Therefore, $\mathrm{SUV}_{\max }$ enables differentiation of benign lung nodules, primary lung cancer, and metastatic lung nodules. Moreover, $\mathrm{MI}_{\max }$ can be used to differentiate benign from malignant lung lesions and malignant lung lesions from metastatic nodules.

Furthermore, 10 of 12 benign lesions by PET-CT were pathologically confirmed (true negative). The 
remaining two patients with a $\mathrm{SUV}_{\max }<2.5$ were pathologically (false-negative) diagnosed with primary lung cancer (adenocancer, mixed type). In the literature, FDG uptake rate of adenocancers with a bronchoalveolar component is significantly lower than that of types without a bronchoalveolar component. ${ }^{[9,25]}$

All 38 lesions identified as malign by PET-CT were pathologically defined as primary lung cancer. Some infective-inflammatory lesions show high F-18 FDG uptake, which can lead to false-positive results. ${ }^{[8]}$

This study was limited by its retrospective design, which prevented control of imaging and patient preparation parameters. Also, a relatively small number of patients was enrolled.

In conclusion, maximum metabolic index value showed a significant correlation with maximum standardized uptake value for benign/malignant discrimination of solitary pulmonary nodules. Maximum standardized uptake value (for 2.59 cut-off value) and mean standardized uptake value (for 1.65 cut-off value) were found to be the most sensitive and specific methods for benign/malignant discrimination in solitary pulmonary nodules. All of the metabolic measurements may discriminate primary lung cancer from the metastatic group.

\section{Declaration of conflicting interests}

The authors declared no conflicts of interest with respect to the authorship and/or publication of this article.

\section{Funding}

The authors received no financial support for the research and/or authorship of this article.

\section{REFERENCES}

1. Ost D, Fein AM, Feinsilver SH. Clinical practice. The solitary pulmonary nodule. N Engl J Med 2003;348:2535-42.

2. Higgins GA, Shields TW, Keehn RJ. The solitary pulmonary nodule. Ten-year follow-up of veterans administration-armed forces cooperative study. Arch Surg 1975;110:570-5.

3. Fischer BM, Mortensen J, Højgaard L. Positron emission tomography in the diagnosis and staging of lung cancer: a systematic, quantitative review. Lancet Oncol 2001;2:659-66.

4. Warburg O. On the origin of cancer cells. Science 1956;123:309-14.

5. Kim SK, Allen-Auerbach M, Goldin J, Fueger BJ, Dahlbom M, Brown M, et al. Accuracy of PET/CT in characterization of solitary pulmonary lesions. J Nucl Med 2007;48:214-20.

6. Gould MK, Maclean CC, Kuschner WG, Rydzak CE, Owens DK. Accuracy of positron emission tomography for diagnosis of pulmonary nodules and mass lesions: a meta-analysis. JAMA 2001;285:914-24.
7. Patz EF Jr, Lowe VJ, Hoffman JM, Paine SS, Burrowes P, Coleman RE, et al. Focal pulmonary abnormalities: evaluation with F-18 fluorodeoxyglucose PET scanning. Radiology 1993;188:487-90.

8. Lowe VJ, Fletcher JW, Gobar L, Lawson M, Kirchner $\mathrm{P}$, Valk $\mathrm{P}$, et al. Prospective investigation of positron emission tomography in lung nodules. J Clin Oncol 1998;16:1075-84.

9. Aquino SL, Halpern EF, Kuester LB, Fischman AJ. FDGPET and CT features of non-small cell lung cancer based on tumor type. Int J Mol Med 2007;19:495-9.

10. Moon SH, Hyun SH, Choi JY. Prognostic significance of volume-based PET parameters in cancer patients. Korean J Radiol 2013;14:1-12.

11. Xie P, Yue JB, Zhao HX, Sun XD, Kong L, Fu Z, et al. Prognostic value of 18F-FDG PET-CT metabolic index for nasopharyngeal carcinoma. J Cancer Res Clin Oncol 2010;136:883-9.

12. Allal AS, Slosman DO, Kebdani T, Allaoua M, Lehmann W, Dulguerov P. Prediction of outcome in head-and-neck cancer patients using the standardized uptake value of 2-[18F] fluoro-2-deoxy-D-glucose. Int $\mathrm{J}$ Radiat Oncol Biol Phys 2004;59:1295-300.

13. Zhao L, Tong L, Lin J, Tang K, Zheng S, Li W, et al. Characterization of solitary pulmonary nodules with $18 \mathrm{~F}$ FDG PET/CT relative activity distribution analysis. Eur Radiol 2015;25:1837-44.

14. Yilmaz F, Tastekin G. Sensitivity of (18)F-FDG PET in evaluation of solitary pulmonary nodules. Int J Clin Exp Med 2015;8:45-51.

15. Sim YT, Goh YG, Dempsey MF, Han S, Poon FW. PET-CT evaluation of solitary pulmonary nodules: correlation with maximum standardized uptake value and pathology. Lung 2013;191:625-32.

16. Sim YT, Poon FW. Imaging of solitary pulmonary nodule-a clinical review. Quant Imaging Med Surg 2013;3:316-26.

17. Lopez OG, Vicente AMG, Martinez AFH, Londono GAJ, Caicedo CHV, Atance PL, et all. 18-FDG PET-CT in the assessment of pulmonary solitary nodules:comparison of different analysis methods and risk variables in the prediction of malignancy. Transl Lung Cancer Res 2015;4:228-35.

18. Lee P, Weerasuriya DK, Lavori PW, Quon A, Hara W, Maxim PG, et al. Metabolic tumor burden predicts for disease progression and death in lung cancer. Int $\mathbf{J}$ Radiat Oncol Biol Phys 2007;69:328-33.

19. Demir Y, Polack BD, Karaman C, Ozdoğan O, Sürücü E, Ayhan S, et al. The diagnostic role of dual-phase (18)F-FDG $\mathrm{PET} / \mathrm{CT}$ in the characterization of solitary pulmonary nodules. Nucl Med Commun 2014;35:260-7.

20. Al-Sugair A, Coleman RE. Applications of PET in lung cancer. Semin Nucl Med 1998;28:303-19.

21. Hashimoto Y, Tsujikawa T, Kondo C, Maki M, Momose M, Nagai A, et al. Accuracy of PET for diagnosis of solid pulmonary lesions with 18F-FDG uptake below the standardized uptake value of 2.5. J Nucl Med 2006;47:426-31.

22. Hain SF, Curran KM, Beggs AD, Fogelman I, O'Doherty MJ, Maisey MN. FDG-PET as a "metabolic biopsy" tool in 
thoracic lesions with indeterminate biopsy. Eur J Nucl Med 2001;28:1336-40.

23. Nguyen NC, Kaushik A, Wolverson MK, Osman MM. Is there a common SUV threshold in oncological FDG PET/CT, at least for some common indications? A retrospective study. Acta Oncol 2011;50:670-7.

24. Yi CA, Lee KS, Kim BT, Choi JY, Kwon OJ, Kim H, et al. Tissue characterization of solitary pulmonary nodule: comparative study between helical dynamic CT and integrated PET/CT. J Nucl Med 2006;47:443-50.

25. Karyagar SS, Koc ZP, Karyagar S, Bekar Y. Diagnostic performance of $18 \mathrm{~F}-\mathrm{FDG} \mathrm{PET} / \mathrm{CT}$ in solitary pulmonary nodules of non-smokers. Turk Gogus Kalp Dama 2017;25:235-41. 